Note

|||||||||||||||||||||||||||||||||||||||||||

\title{
Naturally Occurring Radionuclides of Paper Ashes and Their Effect in the Environment
}

\author{
Asaya KoBASHI \\ Department of Chemistry, Graduate School of Science, The University of Tokyo \\ 7-3-1 Hongo, Bunkyo-ku, Tokyo 113-0033, Japan \\ Received February 1, 2011
}

\begin{abstract}
The concentrations of naturally occurring radionuclides $\left({ }^{226} \mathrm{Ra},{ }^{228} \mathrm{Ra},{ }^{228} \mathrm{Th}\right.$, and $\left.{ }^{40} \mathrm{~K}\right)$ in ashes of papers such as magazines and newspapers were determined from the nuclide concentrations in the papers and the ash contents of the papers. The average ${ }^{226} \mathrm{Ra},{ }^{228} \mathrm{Ra},{ }^{228} \mathrm{Th}$, and ${ }^{40} \mathrm{~K}$ concentrations in the 34 ashes were respectively 27, 68, 75, and $75 \mathrm{~Bq} \mathrm{~kg}{ }^{-1}$. The radium equivalent activities of the ashes were calculated to evaluate the hazard of $\gamma$-ray radiation from the ashes in the environment. A copying paper sample showed a high radium equivalent activity of $602 \mathrm{~Bq} \mathrm{~kg}^{-1}$. However, the average radium equivalent activity was 140 $\mathrm{Bq} \mathrm{kg}^{-1}$ and was lower than the level that causes an environmental health problem.
\end{abstract}

Key Words : paper, paper ash, naturally occurring radionuclides, radioactivity content, radium equivalent activity, municipal waste, incinerator residue, environmental radiation

\section{Introduction}

Large amount of paper is produced, consumed, discarded, and recycled in developed countries. In Japan, $3.06 \times 10^{10} \mathrm{~kg}$ of paper and paper board was produced, and $1.90 \times 10^{10} \mathrm{~kg}$ of waste paper was recycled in the year $2008^{1}$. In the country, combustible municipal waste including paper waste is burned to ash in incinerators. Most of the resulting incinerator residue is buried in disposal sites, and a part of the residue is used as raw material of cement (ecocement) ${ }^{2)}$. In $2008,3.57 \times 10^{10} \mathrm{~kg}$ of combustible municipal waste was incinerated ${ }^{3}$. The weight of paper waste incinerated is calculated to be $1.1 \times 10^{10} \mathrm{~kg}$, because the proportion of paper waste in combustible municipal waste is estimated to be $30 \%^{4)}$. City of Nerima, Tokyo ${ }^{5}$ reported the kinds of papers and their contents of combustible municipal waste collected in the city as follows : magazines, books, wrapping paper, etc., $15.9 \%$; newspaper and inserted bills, $5.4 \%$; corrugated cardboard, $3.7 \%$.

The author ${ }^{6)-8)}$ studied the radioactivity levels of naturally occurring radionuclides in papers, and showed that a number of the paper samples examined contained the nuclides as much as rocks. The conversion of paper waste into ash should concentrate radionuclides contained. This implies that ash produced by combustion of paper waste may increase the radiation levels at disposal sites and places where eco-cement is used.

In this article, the author reports the result of determination of naturally occurring radionuclides in ashes of papers and discusses the hazard of radiation from the ashes in the environment. 


\section{Materials and Methods}

\section{$2 \cdot 1 \quad$ Sample description}

Pocket-sized books, weekly photo magazines, magazines full of color pages, weekly general interest magazines, weekly comic magazines, newspapers, and inserted bills printed between 1999 and 2000 in Japan were examined in this work. Printing papers, copying papers, and notebooks sold between 1999 and 2000 in Japan were also examined in this work. The samples examined were representative of papers that were produced or sold in Japan. The details of the samples were described in the previous articles $^{8), 9)}$. The concentrations of naturally occurring radionuclides $\left({ }^{226} \mathrm{Ra},{ }^{228} \mathrm{Ra},{ }^{228} \mathrm{Th}\right.$, and $\left.{ }^{40} \mathrm{~K}\right)$ in the samples were measured by $\gamma$-ray spectrometry and reported in the earlier article ${ }^{8)}$. The fillers and coating pigments contained in the samples were examined by X-ray diffraction analysis and also reported in the earlier article $^{8)}$.

\section{$2 \cdot 2$ Determination of ash contents}

Except for the printing paper, copying paper, and newspaper samples, more than one kind of paper were used for the samples tested in this work. The weight of samples that were used for the $\gamma$-spectrometry ranged from 0.4 to 1.1 $\mathrm{kg}$. Therefore, samples for determination of ash content were prepared by the following manner : $1.3-2.1$ g portion was cut out by punching a few holes (6.5 mm diameter) in each $\gamma$-ray spectrometry sample in vertical direction to the layer of paper sheets. Each portion obtained was weighed and placed in a porcelain crucible. Then it was burned to ash and ignited at $900{ }^{\circ} \mathrm{C}$ in an electric furnace ${ }^{10)}$. Resulting ash was weighed, and the ash content was calculated.

\section{Results and Discussion}

$3 \cdot 1$ Ash contents and concentrations of naturally occurring radionuclides in the ashes

The result of determination of ash contents is shown in Table 1 . As seen in Table 1 , the ash content varies widely from 3.3 to $29.8 \%$ although paper samples of the same category show comparable ash contents. The average ash content is $13.0 \%$.

The concentrations of naturally occurring radionuclides ${ }^{226} \mathrm{Ra},{ }^{228} \mathrm{Ra},{ }^{228} \mathrm{Th}$, and $\left.{ }^{40} \mathrm{~K}\right)$ in the ashes of the paper samples were estimated from the nuclide concentrations in the samples reported in the author's previous article ${ }^{8)}$ and the ash content data obtained in this work. The result of the estimation is also shown in Table 1. As shown in Table 1, the average ${ }^{226} \mathrm{Ra},{ }^{228} \mathrm{Ra}$, ${ }^{228} \mathrm{Th}$, and ${ }^{40} \mathrm{~K}$ concentrations of the ashes are respectively $27,68,75$, and $75 \mathrm{~Bq} \mathrm{~kg}^{-1}$.

$3 \cdot 2$ Radium equivalent activities of the ashes

The $\gamma$-ray radiation from natural materials is substantially composed of radiations from the following three sources: ${ }^{226} \mathrm{Ra}$ and its descendant nuclides; ${ }^{232} \mathrm{Th}$ and its descendant nuclides $;{ }^{40} \mathrm{~K}$. The intensities of $\gamma$-ray radiation of the above three sources can be expressed respectively by the radioactivities of ${ }^{226} \mathrm{Ra},{ }^{232} \mathrm{Th}$, and ${ }^{40} \mathrm{~K}$. When the health effect of $\gamma$-ray radiation from natural materials is considered, an index is needed to express the total intensity of $\gamma$-ray radiations from the above three sources. Radium equivalent activity ( $\mathrm{Ra}_{\mathrm{eq}}$ ) is such an index for this purpose ${ }^{11)}$. In this index, the radioactivities of ${ }^{232} \mathrm{Th}$ and ${ }^{40} \mathrm{~K}$ are converted to the radioactivity of ${ }^{226} \mathrm{Ra}$, and $\mathrm{Ra}_{\mathrm{eq}}$ is calculated by the following equation : 

their effect in the environment

Table 1 Ash contents of paper samples, radionuclide concentrations in paper ashes, and radium equivalents of paper ashes

\begin{tabular}{|c|c|c|c|c|c|c|c|c|}
\hline \multirow[t]{2}{*}{ Kind of samples } & \multirow[t]{2}{*}{$\begin{array}{l}\text { Number } \\
\text { of } \\
\text { samples }\end{array}$} & \multirow{2}{*}{$\begin{array}{c}\text { Range of } \\
\text { ash } \\
\text { content } \\
\text { (\%) }\end{array}$} & \multirow{2}{*}{$\begin{array}{c}\text { Average } \\
\text { ash } \\
\text { content } \\
\text { (\%) }\end{array}$} & \multicolumn{4}{|c|}{$\begin{array}{l}\text { Average concentrations of radionuclides } \\
\qquad \begin{array}{l}\text { in paper ash } \\
\left(\mathrm{Bq} \mathrm{kg}^{-1)}\right)\end{array}\end{array}$} & \multirow{2}{*}{$\begin{array}{l}\text { Radium } \\
\text { equivalent } \\
\text { of paper ash } \\
(\mathrm{Bq} \mathrm{kg}-1)\end{array}$} \\
\hline & & & & ${ }^{226} \mathrm{Ra}$ & ${ }^{228} \mathrm{Ra}$ & ${ }^{228} \mathrm{Th}$ & ${ }^{40} \mathrm{~K}$ & \\
\hline (A) Pocket-sized book & 5 & $14.8-17.8$ & 16.4 & 39 & 131 & 144 & 114 & 254 \\
\hline (B) Weekly photo magazine & 4 & $21.9-29.8$ & 26.3 & 30 & 76 & 77 & 52 & 144 \\
\hline (C) Magazine full of color pages & 3 & $21.1-23.9$ & 22.4 & 29 & 60 & 64 & 53 & 124 \\
\hline (D) Weekly general interest magazine & 4 & $11.9-12.5$ & 12.1 & 29 & 58 & 62 & 71 & 123 \\
\hline (E) Weekly comic magazine & 4 & $4.9-5.6$ & 5.3 & 21 & 46 & 53 & 95 & 106 \\
\hline (F) Printing paper & 2 & $9.2-11.5$ & 10.4 & 11 & 14 & 17 & 21 & 38 \\
\hline (G) Copying paper & 3 & $3.3-6.6$ & 4.5 & 35 & 116 & 137 & 114 & 241 \\
\hline (H) Notebook & 4 & $5.7-10.5$ & 8.5 & 21 & 44 & 51 & 62 & 98 \\
\hline (I) Newspaper & 3 & $3.3-3.9$ & 3.7 & 14 & 23 & 29 & 76 & 62 \\
\hline (J) Inserted bill & 2 & $19.3-20.5$ & 19.9 & 28 & 64 & 68 & 45 & 129 \\
\hline Whole samples & 34 & $3.3-29.8$ & 13.0 & 27 & 68 & 75 & 75 & 140 \\
\hline
\end{tabular}

$$
\mathrm{Ra}_{\mathrm{eq}}=\mathrm{A}_{\mathrm{Ra}}+\left(\mathrm{A}_{\mathrm{Th}} \times 1.43\right)+\left(\mathrm{A}_{\mathrm{K}} \times 0.077\right)
$$

where $A_{R a}, A_{T h}$, and $A_{k}$ are respectively the radioactivity concentrations of ${ }^{226} \mathrm{Ra},{ }^{232} \mathrm{Th}$, and ${ }^{40} \mathrm{~K}$ in the material of interest.

In Equation 1, it is assumed that the descendants of ${ }^{226} \mathrm{Ra}$ are in radioactive equilibrium with ${ }^{226} \mathrm{Ra}$, and it is also assumed that the descendants of ${ }^{232} \mathrm{Th}$ are in radioactive equilibrium with ${ }^{232} \mathrm{Th}$. As seen in Table 1, the radioactivity concentrations of ${ }^{228} \mathrm{Ra}$ are somewhat lower than those of ${ }^{228} \mathrm{Th}$. It means that the radioactive equilibrium of thorium series nuclides is not closely established in the samples tested. The reason for the disequilibrium can be explained by preferential leaching of ${ }^{228} \mathrm{Ra}$ in production of paper or in preparation of raw materials of paper ${ }^{8)}$. However, thorium series nuclides are nearly in equilibrium in the samples. Therefore, in this work the concentrations of ${ }^{228} \mathrm{Th}$ in the ashes are adopted as $\mathrm{A}_{\text {Th }}$ in Equation 1 , because the $\gamma$-rays of thorium series nu- clides are chiefly made up of $\gamma$-rays from ${ }^{228} \mathrm{Th}$ and its descendant nuclides.

The result of calculation of radium equivalent activities is shown Table 1 and Fig. 1. The average radium equivalent activity of each category is listed in Table 1, and the radium equivalent activities of all the ashes are shown in Fig. 1. Large difference of Raeq value is observed among the samples examined (Fig.1). A copying paper sample (G3) shows a high Raeq value of $602 \mathrm{~Bq} \mathrm{~kg}^{-1}$ whereas a printing paper sample (F1) shows a low Raeq value of 8 . The author ${ }^{8)}$ has demonstrated that the naturally occurring radionuclides in the paper samples were mainly brought with kaolinite used as filler or coating pigment in the papers. G3 sample contained kaolinite and talc as filler, while F1 sample contained calcite as filler and did not contain kaolinite ${ }^{8}$. That is the reason for the large difference in Raeq value between G3 and F1. As shown in Table 1, the average of the radium equivalent activities is $140 \mathrm{~Bq} \mathrm{~kg}^{-1}$. 


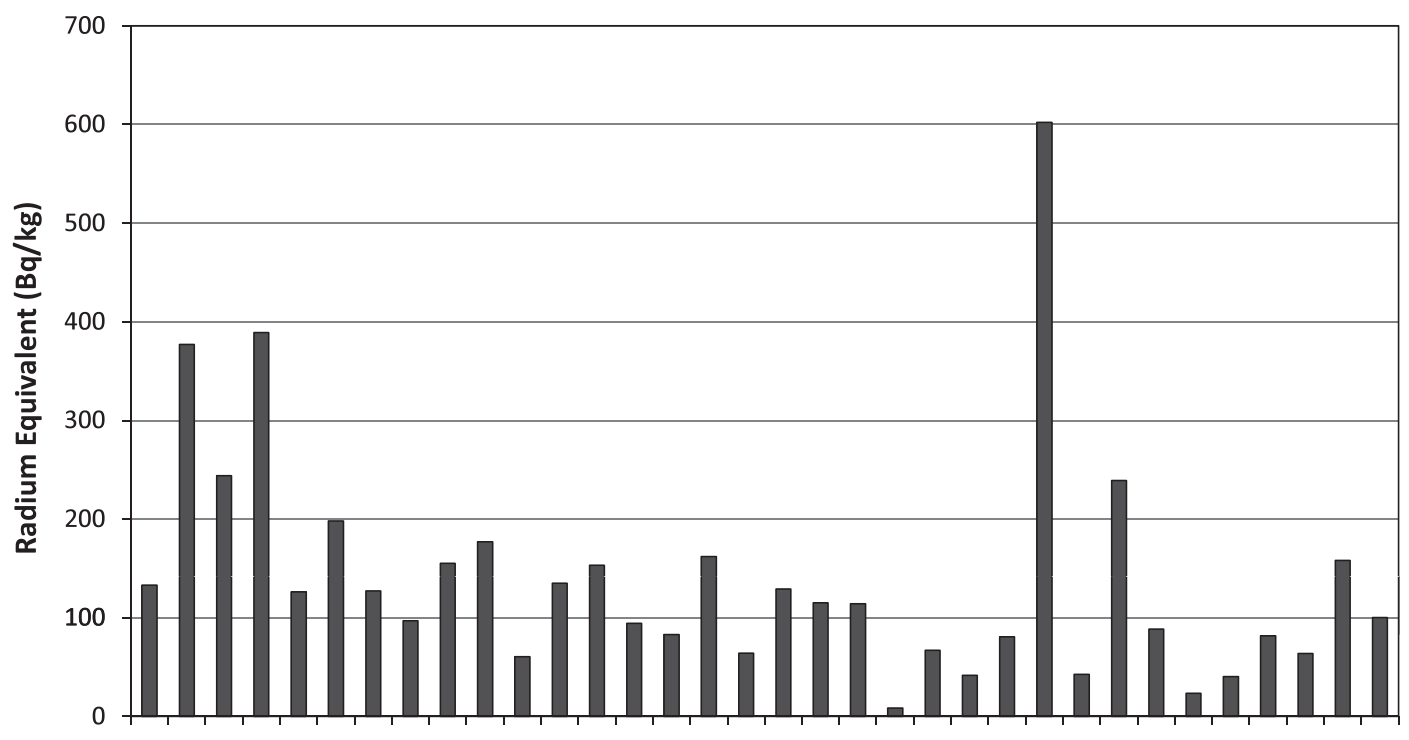

A1 A2 A3 A4 A5 B1 B2 B3 B4 C1 C2 C3 D1 D2 D3 D4 E1 E2 E3 E4 F1 F2 G1 G2 G3 H1 H2 H3 H4 I1 I2 I3 J1 J2

Sample Number

Fig. 1 Radium equivalent activities of ashes from paper samples. Kinds of samples are as in Table 1.

Table 2 Radium equivalent activity

\begin{tabular}{|c|c|c|c|c|}
\hline & \multirow{2}{*}{\multicolumn{3}{|c|}{$\begin{array}{l}\text { Concentrations of radionuclides } \\
\qquad(\mathrm{Bq} \mathrm{kg} \cdot 1)\end{array}$}} & \multirow{3}{*}{$\begin{array}{l}\text { Radium equivalent } \\
\text { radioactivity } \\
\qquad(\mathrm{Bq} \mathrm{kg} \cdot 1)\end{array}$} \\
\hline & & & & \\
\hline & ${ }^{226} \mathrm{Ra}$ & ${ }^{232} \mathrm{Th}$ & ${ }^{40} \mathrm{~K}$ & \\
\hline Earth crust & 11.2 & 14.1 & 282 & 53 \\
\hline Granite & 60 & 80 & 1000 & 251 \\
\hline Limestone & 30 & 7 & 90 & 47 \\
\hline Paper ash (this work) & 27 & 75 & 75 & 140 \\
\hline
\end{tabular}

\section{$3 \cdot 3$ The radioactivity level of the ashes}

As is mentioned in the introduction, ash from combustible municipal waste including paper waste is used as raw material of cement in Japan. As for building materials, some criterions for the limit of radionuclide contents have been proposed. Among such criterions, the following $^{11), 12)}$ is generally accepted: Raeq $<370 \mathrm{~Bq}$ $\mathrm{kg}^{-1}$. Figure 1 shows that three samples (A2, $\mathrm{A} 4$, and G3) represent $\mathrm{Ra}_{\mathrm{eq}}$ values beyond the criterion value. However, the average $\mathrm{Ra}_{\mathrm{eq}}$ value of the paper ashes tested $\left(140 \mathrm{~Bq} \mathrm{~kg}^{-1}\right)$ is fairly lower than the criterion value.

As already mentioned, ash from combustible municipal waste including paper waste is buried in disposal sites in Japan. It is necessary to discuss the question whether paper ashes increase radiation dose rate at disposal sites. Comparison of the Raeq values of paper ashes with those of the earth crust and representative rocks is effective for the discussion. The $\mathrm{Ra}_{\text {eq }}$ value of the earth crust is calculated based 

their effect in the environment

on the average concentration of uranium, thorium, and potassium concentrations in the earth crust $^{13)}$. The Raeq values of granite and limestone are calculated based on the typical concentrations of ${ }^{238} \mathrm{U},{ }^{232} \mathrm{Th}$, and ${ }^{40} \mathrm{~K}$ in granite and limestone ${ }^{14)}$. Granite and limestone are common rocks in the earth crust, and it is known that radiation dose rate is generally higher in granite area than in other rock areas. The result of the calculation is shown in Table 2. As seen in Table 2, the average Raeq value of paper ashes examined in this work is higher than those of the earth crust and limestone, but it is fairly lower than that of granite.

In conclusion, the radioactivity level of the ashes of Japanese papers is not so high that the ashes probably will not cause an environmental health problem.

\section{Acknowledgements}

A part of this research was done in Radioisotope Center, The University of Tokyo.

\section{References}

1) Ministry of Economy, Trade and Industry, the Japanese Government, 2008 Year Book of Paper, Printing, Plastics Products, and Rubber Products Statistics, Economy, Trade and Industry Statistics Association, Tokyo (2009)

2) Anzai, T., Eco-cement challenge to the zero-emission society, Kankyo Kenkyu, 121, 105-111(2001) (in Japanese with English abstract)

3) 2011 Yearbook of Waste, Kankyo Sangyo Shinbun Co., Ltd., Tokyo (2010) (in Japanese)
4) Matsufuji, T., Household Waste, in “Encyclopedia of Refuse”, edited by Kojima, T., Shimada, S., Tamura, S., Nitagai, K. and Yorimoto, K., Maruzen Co., Ltd., Tokyo (2003) (in Japanese)

5) City of Nerima, Handbook of Reduction and Recycle of Waste, City of Nerima, Tokyo(2006) (in Japanese)

6) Kobashi, A., Radioactivity in books printed in Japan : Its source and relation to the year of issue, J. Radiat. Res., 37, 81-95 (1996)

7) Kobashi, A., Radioactivity in newspapers and information business papers, RADIOISOTOPES, 46, 92-95 (1997) (in Japanese with English abstract)

8) Kobashi, A., Radioactivity in papers: The concentration and source of naturally occurring radionuclides, RADIOISOTOPES, 54, 427-435(2005) (in Japanese with English abstract)

9) Kobashi, A., Radioactivity of ${ }^{137} \mathrm{Cs}$ in papers and migration of the nuclide in the environment, $J$. Nucl. Radiochem. Sci., 10, No.2, 1-5(2009)

10) Japan TAPPI, Testing Method of Paper and Paperboard, T413 om-85, Chugai Sangyo Chosakai, Tokyo (1986) (in Japanese)

11) Beretka, J. and Mathew, P. J., Natural radioactivity of Australian building materials, industrial waste and by-products, Health Phys., 48, 87-95 (1985)

12) Mahmoud, K. R., Sharshar, T. M., El-Husseiny, F. A. and Badran, H. M., Natural radionuclides and radiocaesium contained in wood, RADIOISOTOPES, 53, 507-515(2004)

13) Tokyo Astronomical Observatory, Rika Nenpyo (Chronological Scientific Tables), Maruzen Co., Ltd., Tokyo (2004) (in Japanese)

14) Keller, C., Grandlagen der Radiochemie, Otto Salle Verlag GmbH \& Co., Frankfurt (1993) 
要旨

\title{
紙類の灰に含まれる天然放射性核種と健康への影響評価
}

\section{小橋浅哉}

\author{
東京大学大学院理学系研究科化学専攻 \\ 113-0033 東京都文京区本郷 7-3-1
}

雑誌, 新聞等の紙類の灰に含まれる天然放射性核種 ${ }^{226} \mathrm{Ra},{ }^{228} \mathrm{Ra},{ }^{228} \mathrm{Th}$ 及び40 $\left.\mathrm{K}\right)$ の濃度を, 紙 類中のそれらの濃度及び死分量から決定した。34 試料の灰に含まれる ${ }^{226} \mathrm{Ra},{ }^{228} \mathrm{Ra},{ }^{228} \mathrm{Th}$ 及び ${ }^{20} \mathrm{~K}$ の平均濃度は，それぞれ $27,68,75$ 及び $75 \mathrm{~Bq} \mathrm{~kg} \mathrm{~kg}^{-1}$ であった。環境中における紙類の灰からの $\gamma$ 線の有害性を評価するために, 各灰試料のラジウム当量を計算した。コピー用紙の一つは, $602 \mathrm{~Bq}$ $\mathrm{kg}^{-1}$ という高いラジウム当量を示した。しかし, ラジウム当量の平均值は, $140 \mathrm{~Bq} \mathrm{~kg}$-1であり, 環境的な健康問題を起こすレベルではなかった。 